\title{
THE QUASI-DUCTILE RESISTANCE OF COMPRESSED SPUN CONCRETE BEAM-COLUMNS
}

\author{
Romualdas Kliukas ${ }^{1}$, Antanas Kudzys ${ }^{2}$, Romualdas Vadlūga ${ }^{3}$ \\ ${ }^{1,3}$ Vilnius Gediminas Technical University, Sauletekio al. 11, LT-10223 Vilnius, Lithuania \\ ${ }^{2}$ KTU Institute of Architecture and Construction, Tunelio g. 60, LT-44405 Kaunas, Lithuania \\ E-mail: ${ }^{1}$ pirmininkas@vgtu.lt; ${ }^{2}$ antanas.kudzys@gmail.com; ${ }^{3}$ gelz@vgtu.lt \\ Received 07 Oct. 2009; accepted 22 Jan. 2010
}

\begin{abstract}
The expediency of reinforcing precast spun concrete members of annular cross sections reinforced by highstrength steel bars is discussed. Test materials, mechanical properties, production and testing procedures of plain and reinforced spun concrete specimens are presented. The quasi-ductile strength and strain features of concentrically and eccentrically loaded specimens are considered. The modelling of a bearing capacity of beam-columns of annular cross sections is based on the concepts of bending with a concentrical force and compression with a bending moment. The comparison of modelling and test data of spun concrete beam-columns is analysed.
\end{abstract}

Keywords: spun concrete; high-strength steel; tubular members; eccentric loading; compression test.

\section{Introduction}

The high-strength spun (centrifugally cast) concrete with high microcracking and low creep parameters may be successfully used in construction practice. The economically and structurally rational precast spun concrete members reinforced by longitudinal steel bars uniformly distributed throughout their annular cross sections perimeter allow engineers to design and erect columns of contemporary sustainable office or administrative and merchant buildings and some civil engineering works.

In some cases, it is expedient to use prestressed highstrength reinforcing steel bars or tendons and increase a cracking resistance and flexural stiffness of spun concrete slender columns (Quasi 2002). However, a bearing capacity of eccentrically loaded stiff columns reinforced by nonprestressed high-strength steel bars may be significantly greater and more ductile than the prestressed ones.

As it is known, yield strains of reinforcing mild steel bars are lower than ultimate concrete compressive strains of compression members. Contrarily, ultimate strains of high-strength steel bars exceed concrete strains at peak compressive stresses. Thus, high-strength steel bars increase a bearing capacity of compression members due to a redistribution of ultimate compressive stresses between their materials (MacGregor 1988; Kudzys et al. 1993; Kuranovas et al. 2009; Soundararajan et al. 2008). In all cases, longitudinal high-strength steel bars are more effective than high performance steel fibres recommended by Kaufmann et al. (2005).

When the mild steel yields and compressive strength of concrete are obtained at the same compressive strains of about 0.002 the reinforcement of compression members may be treated as balanced. However, the mild steel yiel- ding, usually, occurs before a crushing of high-strength spun concrete and the members is said to be under reinforced. Spun concrete members reinforced by high-strength reinforcement may be much more ductile than these balanced and under-reinforced members with mild steel bars.

The structural performance of tubular members reinforced by high-strength steel bars is based on a small number of specimens. A lack of experimental and theoretical research results hampers the development of analysis methods of these structures. The recommendations and directions presented in design codes Eurocode 2 (2004) and ACI 318-05 (2005) are not fully formulated. In some cases, this can lead to groundless overestimation or underestimation of a bearing capacity and reliability of designed and executed spun concrete tubular structures. The analysis of the bearing capacity of eccentrically loaded spun concrete members reinforced by high-strength steel bars has some characteristic features. Therefore, a reliability verification of these structures in a simple and easily perceptible manner is desired by building engineers.

The data, presented in this paper, belong to the investigations carried out at the Vilnius Gediminas Technical University. The mechanical properties of 181 plain spun concrete hollow cylinders, and 38 concentrically and 31 eccentrically compressed reinforced spun concrete members were investigated experimentally. The test programme was designed to obtain performance data for building and bridge columns.

The object of this paper is testing of the ductility of concentrically and eccentrically compressed reinforced concrete tubular members reinforced by high-strength steel bars and giving structural engineers a possibility to assess their resistance using unsophisticated approaches. 


\section{Materials and specimens}

Spun concrete specimens of annular cross sections were manufactured using crushed granite stone of 5-20 mm size fractions and quartz sand with 2.95-3.05 fineness modulus of $1300-1360 \mathrm{~kg} / \mathrm{m}^{3}$ poured bulk as coarse and fine aggregates of concrete mixtures. The compressive strength at 28 days of Portland cement was equal to 40.2-51.6 MPa. Thus, used mixes belong to high performance concrete mixtures of normal weight spun concrete members (Dilger \& Rao 1997).

The spun concrete specimens were reinforced by ribbed high-strength steel bars of 10, 12 and $14 \mathrm{~mm}$ in diameter. They were uniformly distributed throughout their cross-sectional perimeter. The mean values of $0.2 \%$ proof-stress points, $f_{0.2}$, and ultimate tensile strength, $f_{u}$, of steel bars were 872, 890, 862 and 1060, 1052, $1138 \mathrm{MPa}$. The steel bars satisfied minimum ductility requirements. The deformed steel wire of $5 \mathrm{~mm}$ in diameter and 630-670 MPa in ultimate tensile strength was used as an outer ring and transverse reinforcement with a pitch equal to $100 \mathrm{~mm}$.

Tubular members were moulded by one-layer spinning. Belt-driven and integrated roller and belt-driven type (Fig. 1) centrifugal machines were used for the production of specimens. Their external diameter $d$ (Fig. 2) was equal to 500 and $260 \mathrm{~mm}$. The moulds consisted of two semimoulds 5.000 and $4.800 \mathrm{~mm}$ in length. The rotation speed of moulds during distribution/compacting processes of the concrete mixtures was 115/390 rpm and 250/ $720 \mathrm{rpm}$ for belt-driven and integrated type centrifugal machines, respectively. For the specimens 500 and $260 \mathrm{~mm}$ in diameter the concrete compacting pressures were equal to $0.11-0.2$ and $0.015-0.02 \mathrm{MPa}$. Due to the centrifugation process, a part of the water and cement additives were removed from concrete mixtures. Therefore, their initial water-cement ratio $w_{\text {in }} / c=0.44-0.50$ decreased to the residual water-cement clinker ratio $w_{\text {res }} / c . c \approx 0.38$.

Two groups of plain concrete hollow cylinders consisting of 18 and 28 specimens were produced as additional elements. Their outer diameter and height, $d / h$, were equal to $500 / 400$ and $260 / 300$. They were thermally treated under mild conditions and tested at an age of 3040 days. The other plain concrete specimens were produced together with reinforced concrete members. These specimens were demoulded 3-4 days after production and placed in a room at $19-21^{\circ} \mathrm{C}$ temperature and $70-80 \%$ relative humidity. The reinforced members were tested at an age of 100 days. The plain concrete specimens were tested almost together with reinforced members produced in common batch moulds.

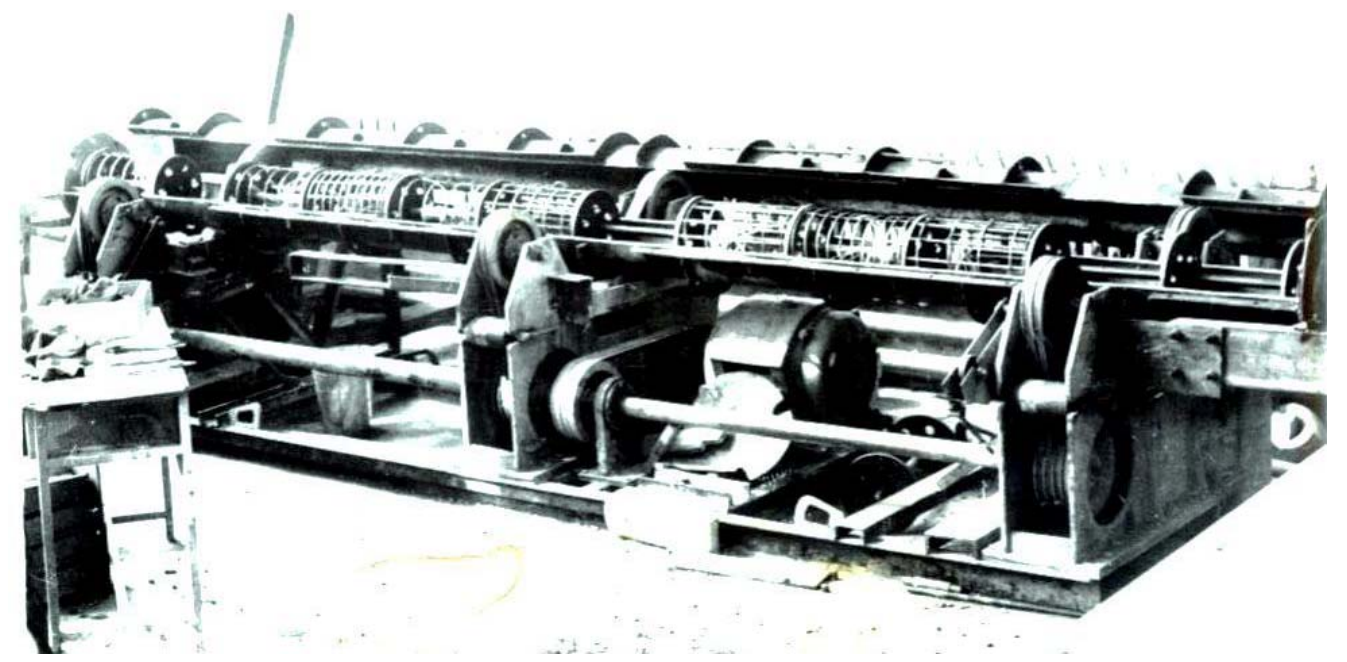

Fig. 1. Integrated roller and belt-driven type centrifugal machine and open semimould with reinforcing carcasses

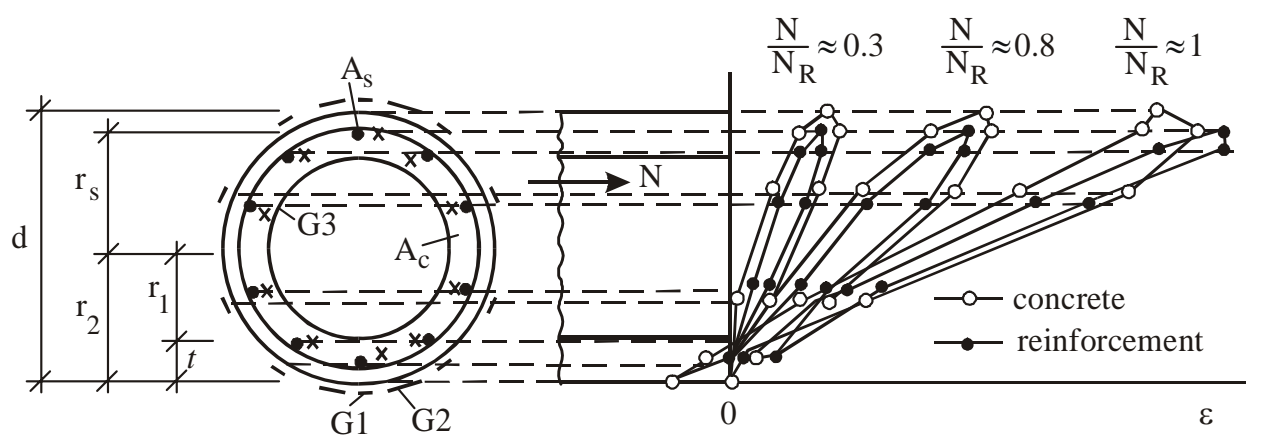

a)

b)

Fig. 2. Spreading of gauges G1, G2, G3 (a), longitudinal strains of concrete and steel bars of eccentrically compressed specimens (b) 
The mechanical properties of the specimens as short tubular columns under compressive loading were determined by the hydraulic jack with a capacity of 500 tons. Bonded steel covers with collars around the specimen ends ensured a normal distribution of compressive stresses. For eccentrically compressed members, the vertical compressive forces were applied through knife-edge supports located at upper and lower plates of a testing machine.

The plain concrete specimens were tested under monotonously increased loads. The test load of reinforced concrete specimens was applied at $7-10 \%$ of its ultimate value $N_{R, o b s}$ at 3-minute intervals. Thus, the test duration of the members was between 30 and 40 minutes.

The longitudinal and transverse strains of the compressive concrete were measured by indicator and electrical-resistance (G1, G2) gauges. The longitudinal strains of reinforcing bars and spirals were measured only by electric-resistance strain gauges G3 (Fig. 2 a). The exactness of measured strains was equal to $\pm 0.5 \times 10^{-6}$. The reading of indicator gauges was fixed by a cinemagraph.

\section{Mechanical properties of plain concrete specimens}

According to González et al. (1974), a strength ratio of plain concrete prisms and cylinders $f_{p r} / f_{c}=0.69-0.93$, the average is equal to 0.85 . According to Eurocode 2 (2004) and ACI Committee 318-05 (2005) directions, the factor 0.85 accounts for strength differences for the concrete in structures and in control cylinders. However, the cylinder strength, $f_{c}$, shall be the only reference strength of spun concrete. It helps engineers use implicitly the recommendations of design codes of concrete structures. An actual strength of plain spun concrete is its strength in hollow cylinders $f_{c 1}$ witch is closed to a prism strength $f_{p r}$.

The compressive strength of spun concrete $f_{c 1}$ of tested specimens was equal to 33-53 MPa. This strength and respective strain $\varepsilon_{c 1}$ of hollow spun concrete cylinders differed from the values $f_{c}$ and $\varepsilon_{c}$ of control vibrated cylinders made of the mix with a decreased watercement ratio residual after centrifugation processes. The ratio $f_{c 1} / f_{c}$ may be also assumed as a constant value and equal to 0.85 irrespective to the spun concrete class.

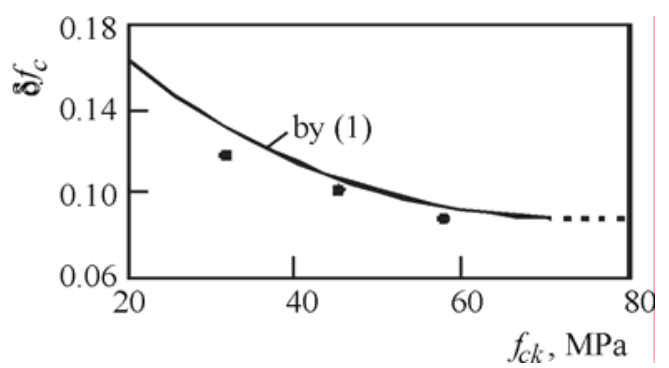

Fig. 3. The coefficient of variation of concrete $\boldsymbol{\delta} f_{c}$ versus its characteristic compressive strength $f_{c k}$
According to the experimental data (Fig. 3), the coefficient of variation of concrete compressive strength, $\boldsymbol{\delta} f_{C}$, may be expressed by the equation:

$$
\boldsymbol{\delta} f_{c}=0.088+3\left(70-f_{c k}\right)^{2} 10^{-5}
$$

where $f_{c k}=20-70 \mathrm{MPa}$ is the characteristic cylinder strength.

The mean value of the modulus of elasticity of normally cured and thermally treated concrete is:

$$
E_{c m}=20 \times\left(0.1 f_{c m}\right)^{0.3},
$$

where $f_{c m}$ is the mean value of its cylinder concrete strength.

Sustained compressive forces may have a considerable effect on the long-term resistance of eccentrically loaded columns. Spun concrete belongs to high-elasticity concretes in which residual microcracks appear when compressive stresses, $\sigma_{c}$, are more than $0.8 f_{c 1}$. Besides, due to marked cement hydration, spun concrete strength increases significantly. After 26 years, its compressive strength increases by 60-70\% (Vadlūga et al. 1996). Therefore, sustained loading may insignificantly reduce a bearing capacity of compression members. This reduction may be evaluated by the factor $\alpha_{c c}$ defined as the function:

$$
\alpha_{C C}=1-\frac{f_{C}^{\prime}}{f_{c 1}}\left(1-\frac{f_{C}^{\prime}}{f_{c 1}}\right) \frac{N_{E P}}{N_{E}} \approx 1-0.1 \frac{N_{E P}}{N_{E}},
$$

where $f^{\prime}{ }_{c}=(0.86-0.91) f_{c 1}$ is the resistance of spun concrete to residual microcracks as its sustained strength; $N_{E}$ and $N_{E P}$ are an applied force and its quasipermanent component, respectively. Thus, the factor $\alpha_{c c}$ may be treated as a linear function the values of which are between 0.9 and 1.0. A low speed loading of test specimens before their compression failure reduced an ultimate strength to $5 \%$ that corresponds to the factor $\alpha_{c C}=0.95$.

The microcracking resistance, $f^{\prime}{ }_{C}$, of vibrated concrete with the prism strength $f_{p r}=30-50 \mathrm{MPa}$ is close to $(0.7-0.76) f_{c 1}$. Therefore, the factor of quasi-permanent load effect by (3) is equal to $k_{p} \approx 1-0.2 N_{E P} / N_{E}$. It corresponds to the data given by Diniz (2002, 2005).

\section{Mechanical properties of reinforced concrete specimens}

An ultimate load of reinforced concrete members was achieved when their concrete cover started to spall. All the failures of tested specimens occurred away from their end zones. The general view of cracking configuration at compressive failure of specimens is shown in Fig. 4. Test relations of the relative compressive forces in specimens $\left(N / N_{u}\right)$, concrete $\left(N_{c} / N_{c u}\right)$, steel bars $\left(N_{s} / N_{s u}\right)$ and compressive strains are presented in Fig. 5. 


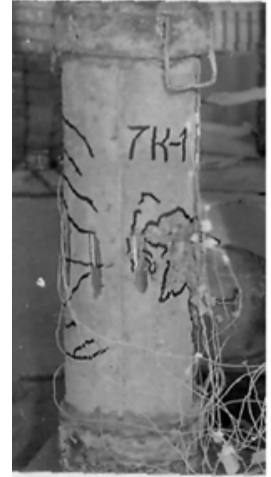

a)

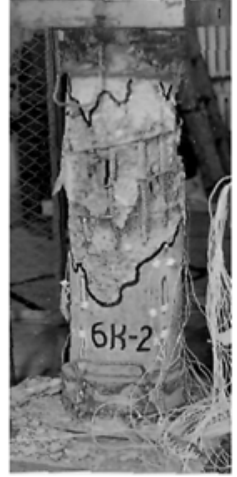

b)

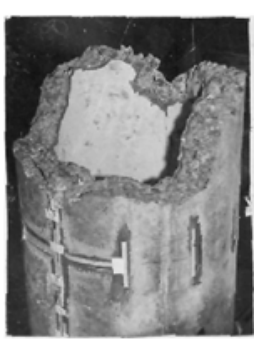

c)
Fig. 4. The characteristic view of concentrically (a) and eccentrically (b) compressed members and concentrically loaded hollow concrete cylinders (c)

The loss of load-carrying capacity of members resulted from concrete cover spalling, longitudinal bar buckling and spiral wire fracture. Spiral fracture occurred from the excessive lateral deformations of longitudinal bars. Their buckling happened after portions of the cracked concrete cover spalled off. Thus, the failure of compressed spun concrete members reinforced by highstrength steel bars may be treated as a plastic one. A relatively brittle failure of specimens occurred when the geometrical reinforcement ratio, $p$, was less than $3 \%$. Therefore, its value of $3-6 \%$ may be considered as a rational reinforcement ratio of spun concrete members reinforced by high-strength steel bars.

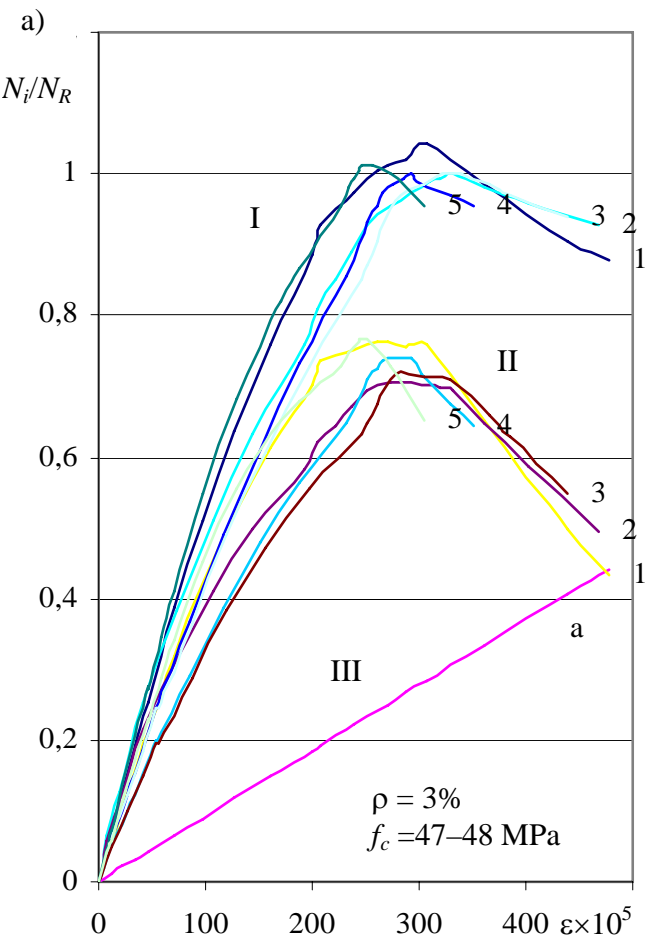

A spiral pitch in $100 \mathrm{~mm}$ did not restrain a lateral expansion of compressive concrete. However, the tested specimens behaved in a relatively ductile manner. Due to an elastic behaviour of high-strength reinforcing bars and a redistribution of stresses, the ultimate compressive strains $\varepsilon_{c u}^{\prime}$ and $\varepsilon_{c u}$ of concrete adjacent with steel bars of respectively concentrically and eccentrically loaded reinforced concrete specimens considerably exceeded the strain $\varepsilon_{c 1}$ of plain concrete specimens (Fig. 6).

The reinforcement of thin-walled structures hinders to compact a concrete mix and in this way decreases its compressive strength $f_{c 1}$ to the value $f_{c 2}$ and increase its strain $\varepsilon_{c 1}$ to the value $\varepsilon_{c 2}$ (Fig. 6).

When the reinforcement ratio $\rho=A_{s} / A_{c}$ is equal to 1.5-6\% and the radius $r_{s}$ is between 100 and $250 \mathrm{~mm}$, the basic mechanical properties of spun concrete in reinforced members are: $f_{c 2}=(0.82-0.96) f_{c 1}$ and $\varepsilon_{c 2}=(2.3-2.4) 10^{-3}$. Thus, the factor characterizing a ratio of concrete strengths in spun concrete members and plain concrete cylinders may be expressed as:

$$
\alpha_{2}=f_{c 2} / f_{c}=0.85-1.7 \rho
$$

This ratio may be assumed as equal to 0.85 when computer controlled centrifugal machines are used.

The compressive strength of spun concrete in structures may be presented in the form:

$$
f_{c c}=\alpha_{C c} \alpha_{2} f_{c} .
$$

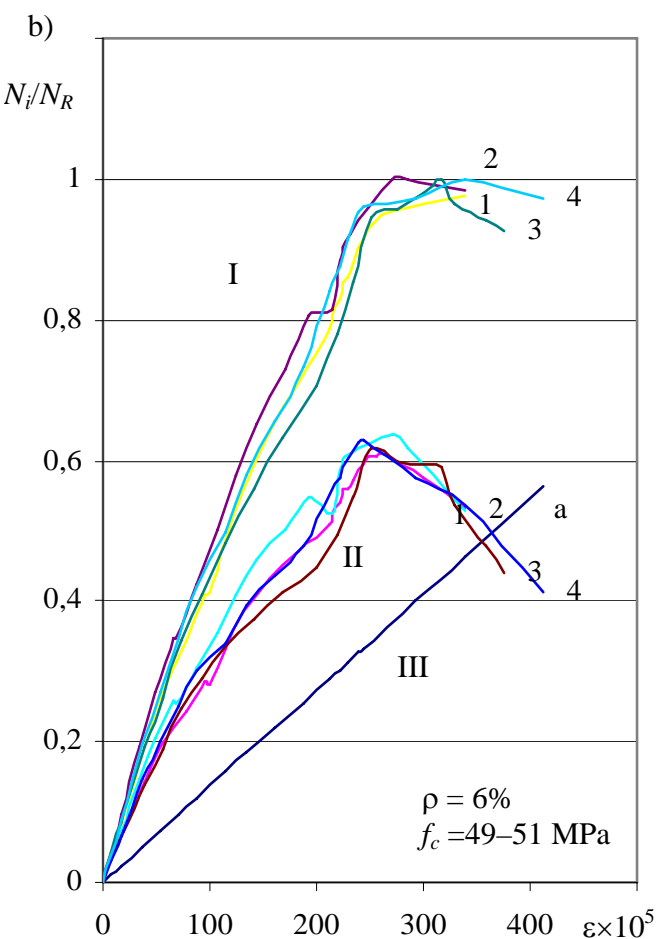

Fig. 5. Testing diagrams of the relative force-strain relation for medium (a) and strong (b) reinforced compressive specimens (I), their concrete (II) and steel bars (III) 


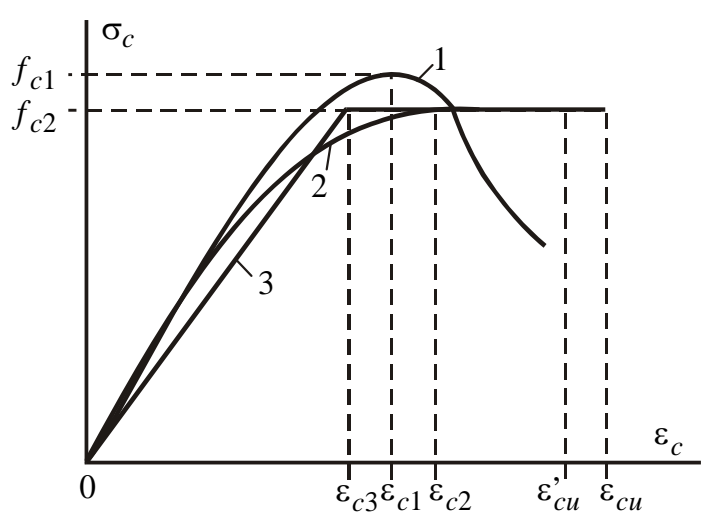

Fig. 6. Stress-strain relations for plain concrete (1) and reinforced concrete by typical (2) and bi-linear (3) laws

Due to a redistribution of compressive stresses of high-strength steel bars and spun concrete, the failure strains of compression members are fairly large. Therefore, the maximum values of spun concrete strains and at the same time of resisting compressive stresses in reinforcing steel bars of concentrically and eccentrically loaded columns may be defined, respectively, as:

$$
\begin{gathered}
\varepsilon_{c u}^{\prime}=2.26(1.18+4 \rho) 10^{-3}, \\
\sigma_{s c}^{\prime}=\varepsilon_{c u}^{\prime} E_{s}=4.52(1.18+4 \rho) 10^{2} \mathrm{MPa}, \\
\varepsilon_{c u}=2.26(1.36+4 \rho) 10^{-3},
\end{gathered}
$$

$$
\sigma_{s c}=\varepsilon_{c u} E_{s}=4.52(1.36+4 \rho) 10^{2} \mathrm{MPa} .
$$

These values are close to stresses calculated by Hussaini et al. (1993) recommendations. The effect of the reinforcement ratio $\rho=A_{s} / A_{c}$ on the ultimate compressive concrete strains is shown in Fig. 7.

The test data disclosed that high-strength and highelastic reinforcing bars decrease the coefficient of variation of concrete strains under the failure of reinforced compression members. Therefore, the use of these bars instead of mild steel ones may efficiently increase the structural safety of spun concrete columns.

\section{Beam-columns under bending with a concentrical force}

The modelling of stress-strain state and bearing capacity of eccentrically loaded spun concrete beam-columns must assess the structural features of annular cross sections and high-strength reinforcing steel bars.

According to the peculiar recommendations, presented by R. Vadlūga (1985), at large values of compressive force eccentricity, the ultimate bending moment of annular cross sections (Fig. 8) reinforced by mild steel bars could be calculated using the expression:

$$
M_{R}=1.2 r_{s}\left(f_{s t} A_{s}+N_{R}\right)\left(1-\alpha_{c}\right) .
$$

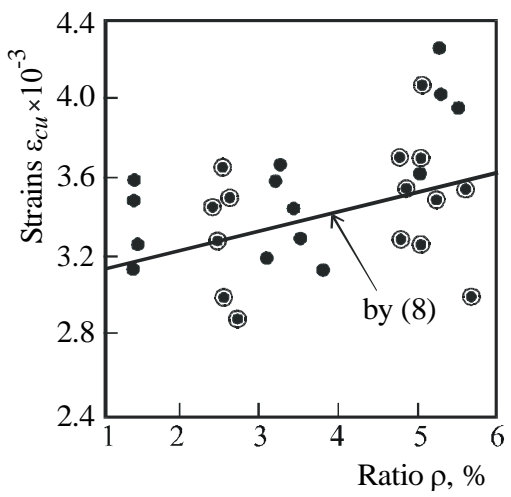

b) Eccentrical loading

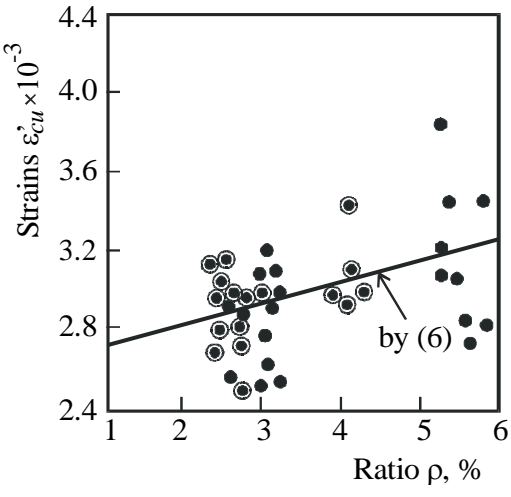

a) Concentrical loading

Fig. 7. Effect of the reinforcement ratio $\rho=A_{s} / A_{c}$ on the ultimate compressive concrete strains of the specimens tested by G. Aksomitas (1984) ( $\left.{ }^{\circ}\right)$ and R. Kliukas (•)

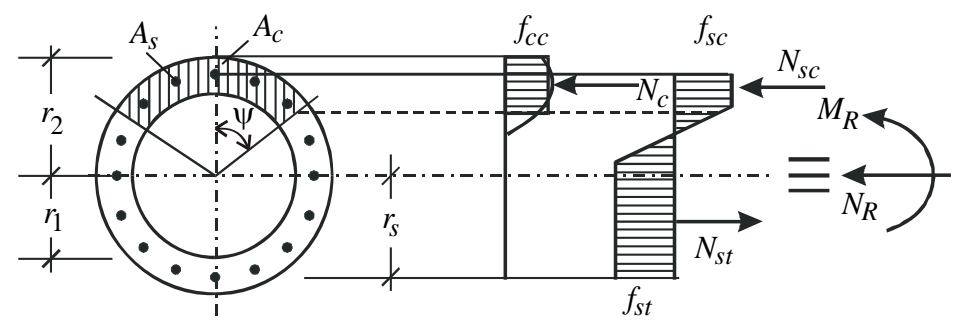

Fig. 8. Modelling of stresses in the concrete and mild steel of eccentrically loaded annular cross sections 
Here the conventional value of the compression zone of section is:

$\alpha_{c}=\psi / \pi=\left(f_{s t} A_{s}+N_{R}\right) /\left[f_{c c} A_{c}+\left(f_{s t}+f_{s c}\right) A_{s}\right]$,

where $f_{s t}$ and $f_{s c}$ are the tensile and compressive strength of longitudinal bars; $A_{s}$ and $A_{c}$ are the areas of steel reinforcement and concrete in the column cross section; $N_{R}$ represents the concentrical force; $f_{c c}$ is the compressive strength of spun concrete defined by Eq. (5).

An analysis of Equation (10) revealed its universality. When tubular members are reinforced by highstrength steel bars, the conventional strengths in tension and compression of reinforcement should be defined as: $f_{s t}=500 \mathrm{MPa}$ and $f_{s c}=600 \mathrm{MPa}$ (Kudzys \& Kliukas 2008). However, when an eccentricity of applied forces is small, it is more expedient to treat tubular columns as members exposed to compression with a bending moment.

The compression of members of annular cross sections may be treated as a loading under small eccentricity $e=M_{E} / N_{E}$ when the ratio $e / r_{s} \leq 1$. In this case, the compressive force is inside of a circle of longitudinal reinforcement.

\section{Beam-columns under compression with a bending moment}

The analysis of ultimate load effects may be based on a plane cross-section hypothesis and bi-linear concrete stress-strain relation when the conventional concrete strain $\varepsilon_{c 3}$ is equal to $0.5 \varepsilon_{c u}$ (Fig. 6). This value is close to strains $\varepsilon_{c 3}$ recommended by Kaufmann (2005).

According to the design model presented in Fig. 9, the resultant internal force as a resisting compressive force and the resisting bending moment caused by this force about the centre point of cross sections are:

$$
\begin{gathered}
N_{R}=N_{c 1}-N_{c 2}+N_{s c}-N_{s t}, \\
M_{R}=N_{c 1} y_{c 1}-N_{c 2} y_{c 2}+N_{s c} y_{s c}+N_{s t} y_{s t} .
\end{gathered}
$$

Thus, the eccentricity of the ultimate compressive force of members is:

$$
e=M_{R} / N_{R}=e_{o} \eta
$$

where $e_{o}$ and $\eta$ are the first-order eccentricity and factor of second-order moment effect of beam-columns (Kudzys \& Kliukas 2009).

Fig. 10 shows that in design practice the response factors characterizing an extent of the intelligent use of the compressive strengthens of concrete and steel bars may be calculated by the formulae:

$$
\begin{gathered}
k_{c}=1-\frac{0.3 e / r_{s}}{1+10 \rho}, \\
k_{s}=1-0.34 e / r_{s} .
\end{gathered}
$$

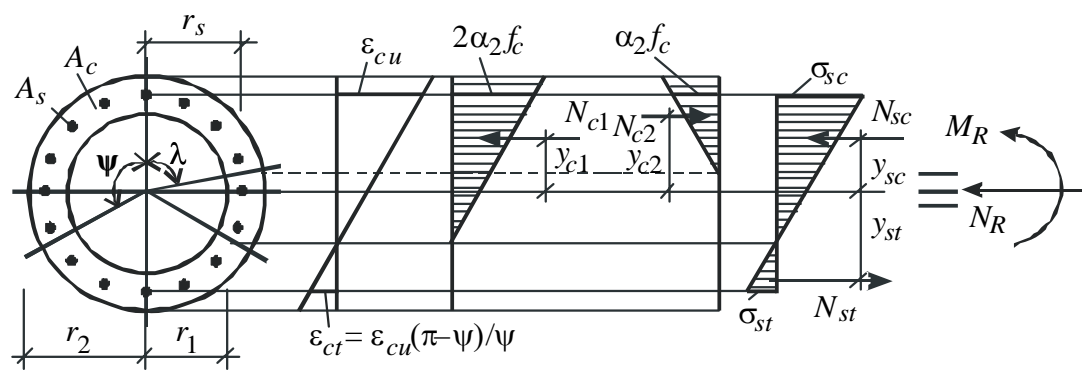

Fig. 9. Modelling of strain and stress distributions in the concrete and high-strength steel of eccentrically loaded annular cross sections

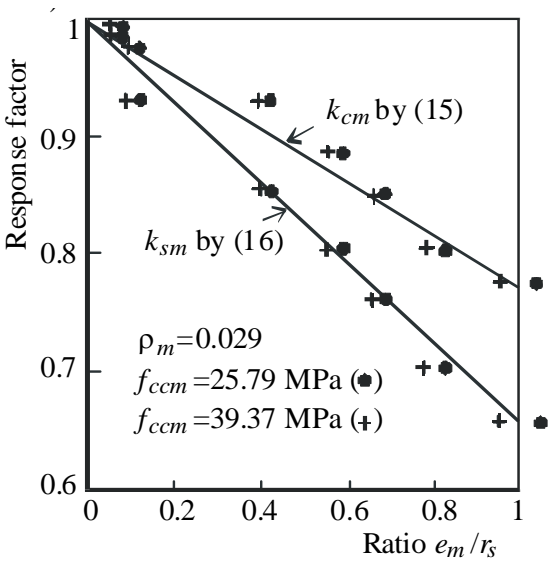

a) Medium reinforcing

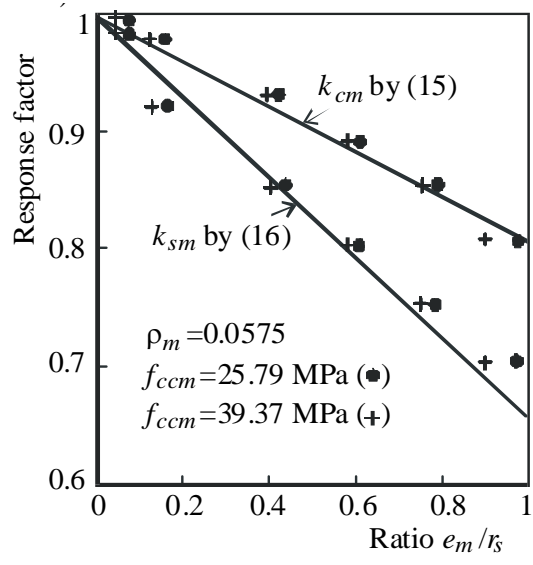

b) Strong reinforcing

Fig. 10. Mean values of response factors of concrete by Eq. (15) and reinforcement by Eq. (16) versus the eccentricity ratio $e_{m} / r_{s}$ 


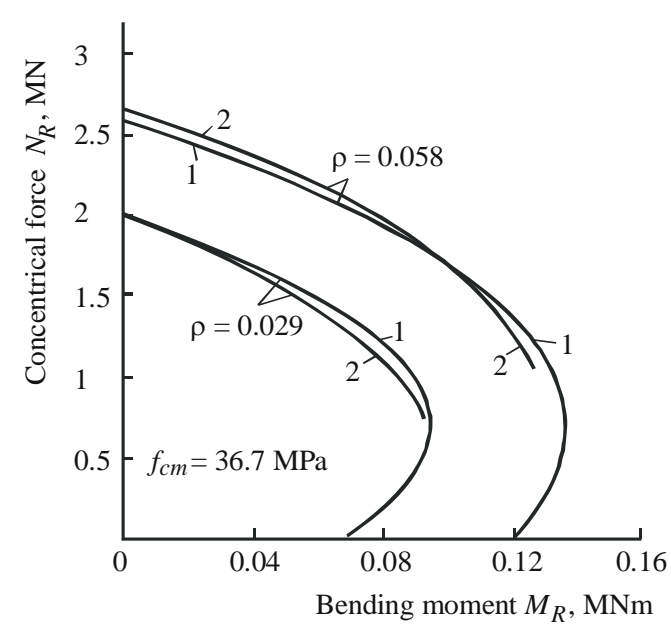

a) Middle-strength concrete

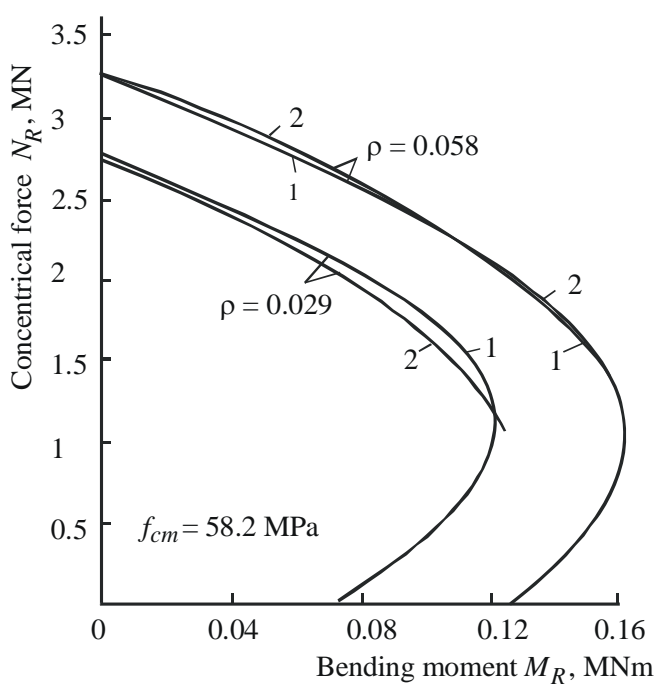

b) High-strength concrete

Fig. 11. Effect of the reinforcement ratio $\rho$ and the compressive concrete strength $f_{c m}$ on the interaction diagram of eccentrically loaded members: $1-M_{R}$ by Eq. (10); $2-M_{R}$ by Eq. (17)

The resisting bending moment and the compressive force of eccentrically loaded members of annular cross sections may be expressed as:

$$
\begin{gathered}
M_{R}=N_{R} e, \\
N_{R}=N_{u c}+N_{u s}=\left(k_{c} f_{c c} A_{c}+k_{s} \sigma_{s c} A_{s}\right) \frac{r_{s}}{e+r_{s}},
\end{gathered}
$$

where $N_{u c}$ and $N_{u s}$ are ultimate compressive forces in concrete and reinforcement components, $k_{c}$ is given by Eq. (15), $k_{s}$ by Eq. (16), $f_{c c}$ by Eq. (5) $\sigma_{s c}$ by Eq. (9). When these members are concentrically loaded, the factors $e=0, k_{c}=k_{s}=1$, and Equation (18) is presented in the form:

$$
N_{R}=f_{C C} A_{C}+\sigma_{S C}^{\prime} A_{s},
$$

where $\sigma_{s c}^{\prime}$ is defined by Eq. (7).

\section{Comparison of modelling and test data}

The comparison of analytical interaction diagrams of eccentrically loaded columns the ultimate bending moments of which are calculated by Eq. (10) and Eq. (17) is given in Fig. 11. It is considered with regard to the reinforcement ratio, $\rho$, equal to 0.029 and 0.058 , and the mean value concrete compressive strength, $f_{c m}$, equal to 36.7 and 58.2 MPa.

The interaction diagram curves 1 and 2 in Fig. 11 were drawn up using fairly simple different analysis models presented in Figs 8 and 9. Nevertheless, these curves are very close. However, when an eccentricity of compressive forces is small $\left(e / r_{s} \leq 1\right)$, it is expedient to use Eq. (18) characterizing the resisting compressive force and in this way to simplify an analysis of tubular columns.

\section{Conclusion}

The presented test and analysis data exposed an possibility to define more exactly the compressive resistance of spun (centrifugally cast) concrete members reinforced by high-strength steel bars uniformly distributed throughout their annular cross sections. The pitch of spiral reinforcement equal to $100 \mathrm{~mm}$ prevents their buckling before concrete failure. It helps avoid a premature failure of compressed tubular members. Compression spun concrete beam-columns reinforced by high-strength steel bars are sufficiently ductile, when the geometrical reinforcement ratio of these members is equal to $3-6 \%$.

When the eccentricity ratio $e / r_{s}<1$, it is expedient to analyse beam-columns as structural members exposed to bending with a concentrical force. In this case, the bearing bending capacity of beam-columns may be calculated by unsophisticated general-purpose Eq. (10).

The loading of tubular members may be looked into compression under small eccentricity when a resultant compressive force is inside their reinforcement circle. In this case, the concept of the compression with a bending moment may be successfully used in the structural analysis of tubular members. The bearing capacity of eccentrically and concentrically compressed members as their resisting compressive force may be calculated by the unsophisticated Equations (18) and (19). The reliability of theses Equations is corroborated by abundant experimental data.

High-strength reinforcing steel bars may effectively increase a bearing capacity and ductility of compressed concrete structures. This virtue of high-strength reinforcement should be legitimated in design codes and standards. The high-strength reinforcing steel bars may be successfully used in the design practice of any in-situ or precast reinforced concrete columns and other compressed members of annular cross sections. 


\section{References}

ACI Committee 318-05. 2005. Building code requirements for structural concrete. American Concrete Institute, Farmington Hills, Mich.

Aksomitas, G. A.; Kudzys, A. P. 1984. On calculation improvement of annular cross-sectional reinforced concrete members with high strength bars under axial compression, Concrete Structures 13: 66-76 (in Russian).

Dilger, W. H.; Rao, S. V. K. M. 1997. High performance concrete mixtures for spun cast concrete poles, PCI Journal, 42(4): 82-89.

Diniz, S. M. C. 2005. Effect of concrete age specification on the reliability of HSC columns, ICOSSAR. Eds. G. Augusti, G. J. Schuëller, M. Ciampoli. Millpress, Rotterdam, 565572.

Diniz, S. M. C. 2002. Long-term reliability of eccentricallyloaded HSC columns, in 6th International symposium on utilization of high strength/high performance concrete, Leipzig, Germany, 2002, 1601-1615.

EN (1992-1) 2004. Eurocode 2: Design of concrete structures Part 1: General rules and rules for buildings, Brussels.

González, O. M.; Robles, F.; Díaz De Cossío. 1974. Strength and deformation of prestressed concrete elements, in Reinforced Concrete Engineering, John Wiley and Sons, New York, 194-301.

Hussaini, A. Al.; Regan, P. E.; Hue, H-Y.; Ramdant, K-E. 1993. The behaviour of HSC columns under axial load, HighStrength Concrete 1: 83-89.

Kaufmann, J. P.; Hesselbarth Moser, K.; Terrasi, G. P. 2005. Application of fiber reinforced high performance composites in spun-cast elements, Materials and Structures 38: 549-555.
Kudzys, A.; Kliukas, R. 2009. The limit state design of spun concrete columns using load combinations recommended by EN 1990 and ASCE/SEI 7-05, Journal of Civil Engineering and Management 15(3): 289-297. doi:10.3846/1392-3730.2009.15.289-297

Kudzys, A.; Kliukas, R. 2008. Precast spun concrete piers in road bridges and footbridges, The Baltic Journal of Road and Bridge Engineering 3(4): 187-197. doi:10.3846/1822-427X.2008.3.187-197

Kudzys, A.; Kliukas, R.; Vadlūga, R. 1993. Utilization of highstrength spun concrete and reinforcing steel in compressive structures, High-Strength Concrete 1: 259-268.

Kuranovas, A.; Goode, D.; Kvedaras, A. K.; Zhong, S. 2009. Load-bearing capacity of concrete-filled steel columns, Journal of Civil Engineering and Management 15(1): 2133. doi:10.3846/1392-3730.2009.15.21-33

MacGregor, J. G. 1988. Reinforced concrete, mechanics and design. Practice-Hall International Inc.

Quast, U. 2002. Columns and masts of prestressed spun concrete, in 6th International Symposium on Utilization of High Strength/High Performance Concrete, Leipzig, Germany, 519-526.

Soundararajan, A.; Shanmugasundaram, K. 2008. Flexural behaviour of concrete-filled steel hollow sections beams, Journal of Civil Engineering and Management 14(2): 107-114. doi:10.3846/1392-3730.2008.14.5

Vadlūga, R. 1985. The evaluation of strength of reinforced concrete members of ring cross-section, Concrete Structures 14: 94-102 (in Russian).

Vadlūga, R.; Kliukas, R.; Garalevičius, R. 1996. Strength and deformability estimation of centrifuged concrete, Journal of Civil Engineering and Management 4(8): 73-83.

\section{TARTUM STAMANTRUS SIJINIŲ KOLONŲ IŠ CENTRIFUGUOTOJO BETONO ATSPARUMAS R. Kliukas, A. Kudzys, R. Vadlūga}

S a n tra k a

Aptariamas didžiastipriais plieniniais strypais armuotų gamyklinių žiedinio skerspjūvio elementų iš centrifuguotojo betono tinkamumas. Pateiktos grynojo ir armuotojo centrifuguotojo betono bandinių medžiagos, mechaninės savybès, gamybos ir bandymo tvarka. Nagrinejjamos centriškai ir ekscentriškai apkrautų bandinių tartum stamantraus stiprumo ir deformacijų ypatybès. Žiedinio skerspjūvio sijinių kolonų laikomajai galiai modeliuoti taikomos gniuždomojo lenkimo ir lenkiamojo gniuždymo sampratos. Analizuojami sijinių kolonų iš centrifuguotojo betono modeliavimo ir bandymo duomenys.

Reikšminiai žodžiai: centrifuguotasis betonas, didžiastipris plienas, žiedinio skerspjūvio elementai, ekscentrinis apkrovimas, gniuždymo bandymas.

Romualdas KLIUKAS. Doctor, Prof, Dept of Strength of Materials, Vilnius Gediminas Technical University, Sauletekio al. 11, LT-10223 Vilnius, Lithuania. PhD (building structures, 1989). Researcher at the Dept of Reinforced Concrete Structures of Vilnius Institute of Civil Engineering. Research visit to Building Scientific-Technical Research Centre (France) 1990-91. Author of over 50 articles. Research interests: capacity, durability and renovation of reinforced vibrated and spun concrete structures, safety and durability of structural members and their systems.

Antanas KUDZYS. Dr Habil, Professor of the Institute of Architecture and Construction of Kaunas Universitty of Technology, Tunelio g. 60, LT-44405 Kaunas, Lithuania. Dr Habil (building structures, 1967). Author of 6 books, 5 textbooks for students, 4 dictionaries and over than 300 articles. Research interest: bearing capacity, safety and durability of structural members and their systems.

Romualdas VADLŪGA. Doctor, Prof, Dept of Reinforced Concrete Structures. Vilnius Gediminas Technical University, Saulètekio al. 11, LT-10223 Vilnius, Lithuania. Doctor's degree in 1967 (building structures). Co-author of 2 textbooks. Lithuanian state prize for technical achievements. Author of more then 120 publications (research and design of reinforced concrete members of circular section). Research interests: mechanics of reinforced concrete structures and estimation of their reliability, thin shells, safety and durability of structural members and their systems. 